\title{
Histopathological analysis of the placental lesions in pregnancies complicated with IUGR and stillbirths in comparison with noncomplicated pregnancies
}

\author{
IUGR ve ölü doğumlarla komplike olmus gebeliklerde plasental lezyonların \\ histopatolojik analizi ve nonkomplike gebeliklerle karşılaştırılması
}

\author{
İlker Günyeli ${ }^{1}$, Evrim Erdemoğlu ${ }^{1}$, Serdar Ceylaner ${ }^{3}$, Sema Zergeroğlu ${ }^{2}$, Tamer Mungan ${ }^{1}$ \\ 'Department of Obstetric and Gynecology, Faculty of Medicine, Süleyman Demirel University, Isparta, Turkey \\ ${ }^{2}$ Department of Pathology, Zekai Tahir Burak Women Health Education and Research Hospital, Ankara, Turkey \\ ${ }^{3}$ Department of Genetics, Zekai Tahir Burak Women Health Education and Research Hospital, Ankara, Turkey
}

\section{Abstract}

Objective: Placental factors and hypoxemia are the keys to intrauter-
ine growth restriction (IUGR) and stillbirth. The aim of the study is to
analyze histological changes in placentas of IUGR fetuses in pregnan-
cies with no apparent etiologic factor and unexplained intrauterine
fetal deaths.

Material and Methods: A total of 110 placentas were collected; 26 placentas of IUGR fetuses with no apparent cause, 58 placentas from unexplained intrauterine deaths over 20 weeks of gestation, and 26 placentas from uncomplicated pregnancies who delivered a healthy live baby. Microscopic examinations of placentas were performed for histopathological analyzes.

Results: Gestational age at delivery was $33.67 \pm 4.37$ weeks, $29.15 \pm 8.36$ weeks, and $39.0 \pm 1.52$ weeks in women in group I, group II and group III, respectively $(\mathrm{p}<0.01)$. Infarction and intervillous thrombosis are significantly more frequent in placentas of Group I and group II. Chronic villitis occurred in $69 \%, 63 \%$ and $30 \%$ of group I, group II, and group III, respectively. Placental intravascular thrombi (Group I, 31\% and group II, 26\%), perivillous fibrin deposition and fibrinoid necrosis (65\% in Group I and 53\% in group II), infarction, intervillous thrombosis, chronic villitis, hemorrhagic endovasculitis, placental intravascular thrombi, perivillous fibrin deposition, fibrinoid necrosis, erythroblastosis and villous edema were found in the study group.

Conclusion: The results reported here indicate that a relationship exists between morphological changes in the placentas of IUGR and intrauterine fetal deaths (J Turkish-German Gynecol Assoc 2011; 12: 75-9) Key words: Stillbirth, intrauterine growth restriction, histopathology, placenta, light microscopy

Received: 22 January, 2011

Accepted: 22 April, 2011
Özet

Amaç: Plasental faktörler ve hipoksemi, intrauterine gelişme geriliği (IUGR) ve intrauterine eksituslar da ana nedenlerdir. Çalışmanın amacı etyolojik nedeni tespit edilemeyen IUGR'li fetüslerin ve açılanamayan intrauterine ölümlerin plasentalarındaki histolojik değişikliklerin analizini yapmaktır.

Gereç ve Yöntemler: Bilinen bir sebebi olmayan 26 IUGR'lı fetüsün plasentası, 20 haftanın üzerinde 58 açıklanamayan intrauterine eksituslu fetüsün plasentası ve 26 sağlıklı nonkomp-like canlı yenidoğanın plasentası olmak üzere toplam 110 plasenta toplandı. Histopatolojik analiz için plasentaların mikroskopik incelemesi yapıldı.

Bulgular: Grup I, grup II ve grup III'ün doğum anındaki gestasyonel haftaları, sırasılya, $33.67 \pm 4.37$ hafta, $29.15 \pm 8.36$ hafta ve $39.0 \pm 1.52$ hafta idi. IUUGR'li fetüsler ve ölü bebek-lerin plasentalarında enfarktüs ve intervillöz trombozis anlamlı olarak daha fazlaydı. Kronik villitis, grup I, Grup II ve grup III'de sırasıyla $\% 69, \% 63$ and \%30 oranında idi. Çalışma grubunda plasental intravasküler trombüs (Grup I'de \%31, grup II'de \%26), perivillöz fibrin depozitleri ve fibrinoid nekroz (Grup I'de $\% 65$ ve grup II'de \%53) ve ayrıca enfarktüs, in-tervillöz tromboz, kronik villitis, hemorajik endovaskülitis, plasental intravasküler thrombus, perivillöz fibrin depozitleri, fibrinoid nekrozis, eritroblastozis ve villöz ödem varlı̆̆ı tespit edildi.

Sonuç: Çalışmamızın sonuçları, intrauterin gelişme gerilikli fetüsler ile intrauterine ölüm olan fetüslerin plasentalarındaki morfolojik değişiklikler arasında ilişki olduğunu göstermektedir.

(J Turkish-German Gynecol Assoc 2011; 12: 75-9)

Anahtar kelimeler: Ölü doğum, intra uterin gelişme geriliği, histopatoloji, plasenta, ışık mikroskopi

Geliş Tarihi: 22 Ocak 2011

Kabul Tarihi: 22 Nisan 2011

\section{Introduction}

Fetal growth and viability depends on the maternal supply of nutrients and oxygen through the placenta into the umbilical circulation. Placental factors and hypoxemia are keys to intrauterine growth restriction (IUGR) and fetal death. IUGR is a condition associated with placental insufficiency (1). Adaptive changes in IUGR may fail at some point, leading to fetal death. Conditions resulting in placental dysfunction can be recurrent. The placental complications may manifest in different ways in different pregnancies; IUGR in one pregnancy and fetal death in another pregnancy $(2,3)$. Faulty placentation has been linked to the pathogenesis of preeclampsia, preterm births, abortions, IUGR and intrauterine death $(4,5)$. IUGR may be caused by fetal, placental, or maternal factors. These factors are usually multiple and overlapping. 
The most common causes of stillbirth between 24 and 27 weeks of gestation are infection, abruption and fetal anomalies. Unexplained stillbirth is a fetal death that cannot be attributed to an identifiable fetal, placental, maternal, or obstetrical etiology, and accounts for $60 \%$ of fetal deaths $(6,7)$. The most frequent cause of stillbirth after 28 gestational weeks is unexplained fetal loss. Unexplained fetal loss includes stillbirths associated with growth restriction and placental abruption (6). Information on placental abnormalities may reveal the presence of chronic fetal insults and allow their differentiation from acute (peripartum) stresses (8). The aim of the present study is to analyze histological changes in placentas of IUGR fetuses, in placentas of unexplained intrauterine death fetuses and in uncomplicated pregnancies.

\section{Material and Methods}

\section{Patients}

A total of 110 placentas were collected; 26 placentas of IUGR fetuses (Group I) with no apparent cause, 58 placentas from unexplained intrauterine deaths over 20 weeks of gestation (Group II) and 26 placentas from uncomplicated term pregnancies in whom a healthy live baby was delivered (Group III). Gestational ages were 33.67 \pm 4.37 weeks, $29.15 \pm 8.36$ weeks, and $39.0 \pm 1.52$ weeks in women with group I, group II and group III, respectively $(\mathrm{p}<0.01)$. (Table 1$)$. The study was approved by the Institutional Review Board and informed consent has been obtained from all the patients.

Multiple pregnancies, fetuses with a chromosomal anomaly or congenital anomaly, and fetuses with hydrops fetalis were excluded from this study. Maternal exclusion criteria were preeclampsia, diabetes mellitus, infection, placental tumors and trauma. In addition, women with antenatal hemorrhage (placental abruption, vasa previa and placenta previa), and women diagnosed with any systemic disorder were excluded from the study. Fetal death was defined as a lack of fetal heart activity diagnosed by ultrasound examination. IUGR was defined on the basis of an estimated fetal weight of less than the third percentile for gestational age (9), reduced amniotic fluid volume or Doppler ultrasound of the umbilical artery demonstrating absent end diastolic flow velocity. The diagnosis of IUGR was established by serial ultrasonographic examination of fetal biometric measurements (weight, biparietal diameter, head circumference, femur length, and abdominal circumference).

\section{Sample collection and histological analyses}

Immediately after delivery, placentas were fixed with $10 \%$ formalin for 24 hours and processed for routine paraffin embeding. Multiple random samples were taken from each placenta from a macroscopically normal central portion of the placenta, including two samples of umbilical cord (one close to the distal

Table 1. Demographic and obstetric characteristics of patients

\begin{tabular}{|l|c|c|c|c|}
\hline & Group 1 & Group 2 & Group 3 & p \\
\hline Mean of age & $26.5 \pm 6.05$ & $26.77 \pm 6.08$ & $25.8 \pm 4.94$ & \multirow{2}{*}{ p $>0.05$} \\
\cline { 1 - 4 } Gravida & $2.27 \pm 1.64$ & $2.60 \pm 1.90$ & $2.58 \pm 1.38$ & \\
\hline Parity & $0.81 \pm 1.2$ & $1.1 \pm 1.35$ & $1.66 \pm 1.08$ & \\
\hline $\begin{array}{l}\text { Gestational } \\
\text { age at delivery }\end{array}$ & $33.67 \pm 4.37$ & $29.15 \pm 8.36$ & $39.0 \pm 1.52$ & $\mathrm{p}<0.01$ \\
\hline
\end{tabular}

end and one from within $10 \mathrm{~cm}$ of the insertion on the chorionic plate), two samples of the extra placental membranes (one from the edge of the site of rupture when identifiable, one from a membrane roll extending from the site of rupture to the placental margin), and at least one sample of chorionic plate consisting of chorionic vessels. For all cases, 4 sections of 4 $\mu \mathrm{m}$ thickness were cut on a rotary microtome from the middle of each specimen, and were mounted on clean gelatinized slides, and stained with $\mathrm{H} \& \mathrm{E}$. Sections were analyzed by light microscopy and in each of the placental slides, the 10 smallest terminal villi (each less than $80 \mu \mathrm{m}$ in diameter) in 10 different fields were examined (magnification $\times 400$ ). The observations were recorded by digital camera (Olympus ${ }^{\circledR}$ DP70, Japan). Microscopic evaluation of placentas included non-inflammatory changes of amnion, acute inflammatory changes, infarction, intervillous thrombosis, chorionic villitis, hemorrhagic endovasculitis, placental intravascular thrombi, trophoblast degenerative knots, perivillous fibrin deposition and fibrinoid necrosis, erythroblastosis and villous edema (Table 2) (8). (Fig. 1, 2). The researchers examining the tissue sections were blinded to the clinical details of the cases.

\section{Statistical analysis}

Statistical analyses were performed using the chi-square test for categorical variables. Continuous variables were compared by the Student's t-test. $\mathrm{p}<0.05$ was considered significant. All computations were carried out with SPSS software 13.0 (SPSS inc. Chicago, Illinois, USA).

\section{Results}

Means of age, gravida and parity of patients were similar in group I, group II and group III. Gestational age at delivery was $33.67 \pm 4.37$ weeks, $29.15 \pm 8.36$ weeks, and $39.0 \pm 1.52$ weeks in women in group I, group II and group III, respectively $(\mathrm{p}<0.01)$. (Table 1).

Microscopic examination revealed no significant difference between the three groups in respect to non-inflammatory changes of amnion, acute inflammatory changes and trophoblastic degenerative knots ( $p>0.05)$. Statistically significant light microscopy findings are shown in Table 3 . Infarction and intervillous thrombosis are significantly more frequent in placental cotyledons of group I and group II fetuses. The most common associated pathologic condition with infarction and thrombosis was chronic villitis in both groups (Fig. 2).

Chorionic villitis occurred in $69 \%, 63 \%$ and $30 \%$ of group I, group II, and group III, respectively. There was one case (3.8\%) of hemorrhagic endovasculitis in the control group $(\mathrm{p}<0.05)$. Thirty one percent of placentas in group I and $28 \%$ of placentas in group II had hemorrhagic endovasculitis. The volume of affected tissue was similar in group I and group II.

There was no case of intravascular thrombi in the control group. However, $31 \%$ and $26 \%$ of placentas of group I and group II had placental intravascular thrombi $(\mathrm{p}<0.01)$. Thrombi were only detected in chorionic vessels (Fig. 2). The number of affected vessels is shown in Table 3. Perivillous fibrin deposition and fibrinoid necrosis was more common in group I (65\%) and group II $(53 \%)$ compared to group III $(11 \%, p<0.01)$. (Fig.1). The incidence of erythroblastosis and villous edema were significantly higher in the group I and group II than the control one $(p=0.01)$. 
Table 2. Parameters for microscopic evaluation of placenta (8) (Figure 1 and 2)

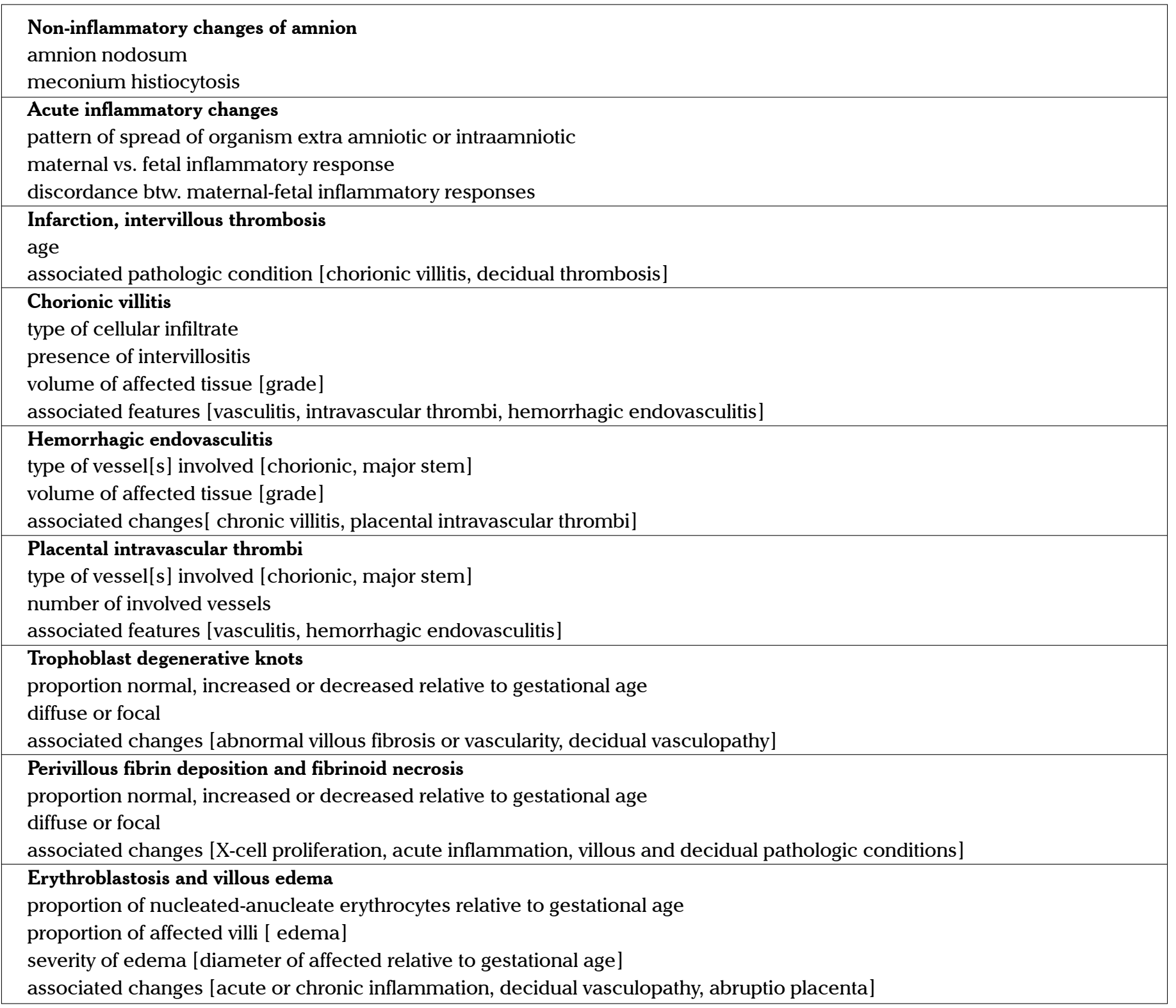

\section{Discussion}

Placental pathology in intrauterine growth restriction and fetal demise after 20 weeks of gestation are investigated in this study. In this analysis, we intentionally did not include any women with a particular clinical risk factor (such as preeclampsia, or gestational diabetes) along with intrauterine death or intrauterine growth restriction. Although gestational ages of the groups were different, this study provides important results in placentas of IUGR fetuses and intrauterine death fetuses. Amnion nodosum is commonly regarded as a placental hallmark of severe and prolonged oligohydramniosis (10). Meconium histiocytosis reflects the duration of exposure to meconium before delivery. Acute placental inflammation is usually related to clinical situations such as premature rupture of the membranes and preterm delivery. Although these lesions are associated with chronic uterine vascular insufficiency, neither of them was found to be significantly different among the groups.
Placental infarction can be observed in many normal pregnancies. It is usually of no significance unless it affects more than $10-20 \%$ of the placental volume (11). The existence of a relation between fetal hypoxia and placental infarction has been shown (12). In the present study, placental infarction was detected in 58\% and $62 \%, 4 \%$ of group I, group II and group III, respectively. Intervillous thrombosis was only observed in placentas of intrauterine death fetuses and may be feature of intrauterine death (Fig. 2).

It is reported that fetal thrombotic vasculopathy and fetal stem vessel thrombosis are common findings in women with adverse pregnancy outcomes (13). In the present study, no major stem occlusion was found in the placentas of group I or group II fetuses. Thirty-one percent of group I fetuses and $26 \%$ of group II fetuses had chorionic vessel occlusion. However, none of the placentas from healthy babies had placental intravascular thrombi $(p<0.05)$. In contrast, occlusion of $<50 \%$ of the lumen are not uncommon at term and this is reported to be a preparation for parturition (8). 
Table 3. Statistically significant light microscopy findings in placentas of fetuses with intrauterine growth restriction (Group I) and placentas of stillbirths (Group II), and healthy live babies (Group III) (Student's t-test)

\begin{tabular}{|c|c|c|c|c|}
\hline Comparision of Histopathological Analyses & $\begin{array}{c}\text { Group I } \\
\text { n [\%] }\end{array}$ & $\begin{array}{c}\text { Group II } \\
\text { n [\%] }\end{array}$ & $\begin{array}{c}\text { Group III } \\
\text { n [\%] }\end{array}$ & $\begin{array}{c}\mathbf{P} \\
\text { value }\end{array}$ \\
\hline Infarction, intervillous thrombosis & $15[58]$ & 39 [67] & $1[4]$ & \multirow[t]{8}{*}{$<0.01$} \\
\hline Infarction & 15 [ 57.7] & $36[62]$ & $1[4]$ & \\
\hline intervillous thrombosis & -- & $2[3]$ & - & \\
\hline Infarction and intervillous thrombosis & -- & $1[2]$ & - & \\
\hline associated pathologic condition & $14[54]$ & 34 [59] & $1[4]$ & \\
\hline chorionic villitis & $10[39]$ & $21[36]$ & $1[4]$ & \\
\hline decidual thrombosis & $4[15]$ & $9[16]$ & -- & \\
\hline chorionic villitis and decidual thrombosis & -- & $4[7]$ & -- & \\
\hline Chorionic villitis & 18 [69] & $37[64]$ & $8[31]$ & $<0.5$ \\
\hline Hemorrhagic endovasculitis & $8[31]$ & $16[28]$ & $1[4]$ & \multirow[t]{8}{*}{$<0.5$} \\
\hline \multicolumn{4}{|l|}{ type of vessel[s] involved } & \\
\hline chorionic & $8[31]$ & $15[26]$ & $1[4]$ & \\
\hline major stem & -- & $1[2]$ & -- & \\
\hline \multicolumn{4}{|l|}{ volume of affected tissue[grade] } & \\
\hline grade 1 & $1[4]$ & $4[7]$ & $1[4]$ & \\
\hline grade 2 & $6[23]$ & $10[17]$ & - & \\
\hline grade 3 & $1[4]$ & $2[3]$ & - & \\
\hline Placental intravascular thrombi & $8[31]$ & $15[26]$ & - & \multirow[t]{6}{*}{$<0.5$} \\
\hline \multicolumn{4}{|l|}{ type of vessel[s] involved } & \\
\hline chorionic & $8[31]$ & $15[26]$ & & \\
\hline major stem & -- & -- & & \\
\hline \multicolumn{4}{|l|}{ number of involved vessels } & \\
\hline 1 & $2[8]$ & $2[3]$ & & \\
\hline 2 & $5[19]$ & $12[21]$ & & \\
\hline more than 2 & $1[4]$ & $1[2]$ & & \\
\hline Perivillous fibrin deposition / fibrinoid necrosis & $17[65]$ & $31[53]$ & $3[12]$ & \multirow[t]{9}{*}{$<0.01$} \\
\hline Perivillous fibrin deposition & $16[62]$ & $29[50]$ & -- & \\
\hline fibrinoid necrosis & $1[4]$ & $2[3]$ & $3[12]$ & \\
\hline Perivillous fibrin deposition with fibrinoid necrosis & -- & -- & -- & \\
\hline \multicolumn{4}{|l|}{ proportion relative to gestational age } & \\
\hline normal & $8[31]$ & $16[28]$ & $2[8]$ & \\
\hline increased & $8[31]$ & $12[21]$ & $1[4]$ & \\
\hline decreased & $1[4]$ & $3[5]$ & - & \\
\hline \multicolumn{4}{|l|}{ diffuse or focal } & \\
\hline diffuse & $12[46]$ & $18[31]$ & $2[8]$ & \\
\hline focal & $5[19]$ & $13[22]$ & $1[4]$ & \\
\hline Erythroblastosis / villous edema & $12[46]$ & $28[48]$ & $7[27]$ & \multirow[t]{4}{*}{$<0.01$} \\
\hline Erythroblastosis & $5[19]$ & $5[9]$ & -- & \\
\hline villous edema & $3[12]$ & $7[12]$ & $6[23]$ & \\
\hline Erythroblastosis and villous edema & $4[16]$ & $16[28]$ & $1[4]$ & \\
\hline
\end{tabular}




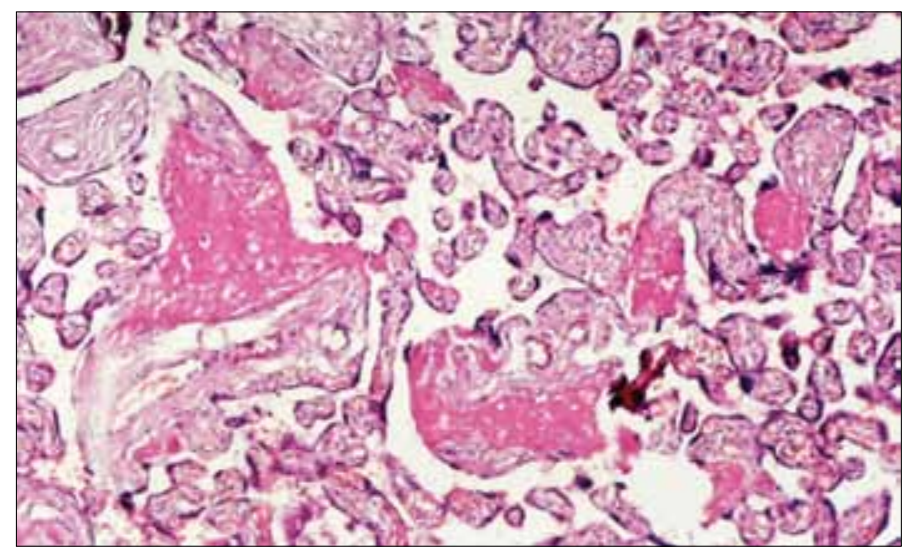

Figure 1. Histopathological section of perivillous fibrin deposits in placenta of IUGR fetus. H\&E, x400

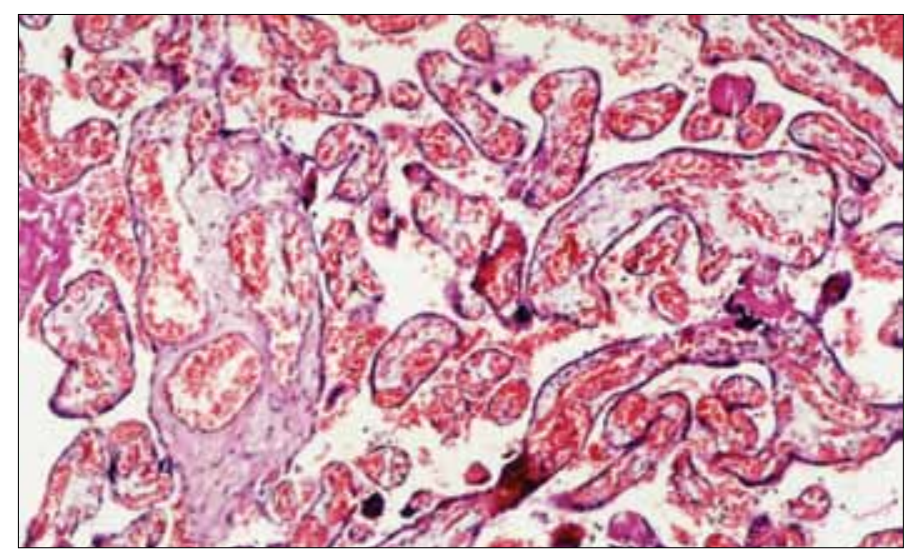

Figure 2. Histopathological section of villous thrombosis in intrauterine death fetus pla-centas. $\mathrm{H} \& \mathrm{E}, \mathrm{x} 400$

Large areas of the placenta may be affected by different lesions without any obvious danger to the fetus. It is evident that the number of different types of lesions that are seen is far more strongly associated with fetal growth restriction or intrauterine death than the presence or severity of any one lesion (14). It is more likely that accumulation of placental injury for a sufficient duration leads to IUGR and fetal death (15).

Fibrinoid necrosis and perivillous fibrin deposition are associated with IUGR, autoimmune processes, infection, toxic insult, a known abnormal host-placenta interaction, genetic disorders and confined placental mosaicism (16-19). Perivillous fibrin deposition and fibrinoid necrosis were significantly more frequent in group I and group II compared to group III (Fig. 1). The presence of excess erythroblasts in the placental circulation suggests a response to hematopoietic stress (14). Villous edema may be observed in several situations like hydrops fetalis and acute intraamniotic infection (20). In this study erythroblastosis together with villous edema were found to be significantly more common in complicated pregnancies.

Infarction, intervillous thrombosis, chorionic villitis, hemorrhagic endovasculitis, placental intravascular thrombi, perivillous fibrin deposition, fibrinoid necrosis, erythroblastosis and villous edema were found to be the types of lesions that cause a normal fetus to become growth restricted or die (Fig. 1, 2). However, the extent of these lesions and clinical outcomes could not be clearly defined. The results reported here indicate that a relationship exists between morphological changes in the placentas of IUGR fetuses and intrauterine death fetuses.

\section{Conflict of interest}

No conflict of interest was declared by the authors.

\section{References}

1. Pardi G, Marconi AM, Cetin I. Placental-fetal interrelationship in IUGR fetuses: a review. Placenta 2002; 23: 136-41. [CrossRef]

2. Chaiworapongsa T, Romero R, Kusanovic JP, Savasan ZA, Kim SK Mazaki-Tovi S, et al. Unexplained fetal death is associated with increased concentrations of anti-angiogenic factors in amniotic fluid. J Matern Fetal Neonatal Med 2010; 23: 794-805. [CrossRef]

3. Canterino JC, Ananth CV, Smulian J, Harrigan JT, Vintzileos AM. Maternal age and risk of fetal death in singleton gestations: USA, 1995-2000. J Matern Fetal Neonatal Med 2004; 15: 193-7.

4. Redline RW. Placental pathology: a neglected link between basic disease mechanisms and untoward pregnancy outcome. Curr Opin Obstet Gynecol 1995; 7: 10-5.

5. Ness RB, Sibai BM. Shared and disparate components of the pathophysiologies of fetal growth restriction and preeclampsia. Am J Obstet Gynecol 2006; 195: 40-9. [CrossRef]

6. Fretts RC, Boyd ME, Usher RH, Usher HA. The changing pattern of fetal death, 1961-1988. Obstet Gynecol 1992; 79: 35-9.

7. Huang DY, Usher RH, Kramer MS, Yang H, Morin L, Fretts RC. Determinants of unex-plained antepartum fetal deaths. Obstet Gynecol 2000; 95: 215-21.

8. Tantbirojn P, Saleemuddin A, Sirois K, Crum CP, Boyd TK, Tworoger $\mathrm{S}$, et al. Gross ab-normalities of the umbilical cord: related placental histology and clinical significance. Placenta 2009; 30: 1083-8. [CrossRef]

9. Altman DG, Coles EC. Nomograms for precise determination of birth weight for dates. Br J Obstet Gynaecol 1980; 87: 81-6. [CrossRef]

10. Adeniran AJ, Stanek J. Amnion nodosum revisited: Clinicopathologic and placental corre-lations. Arch Pathol Lab Med 2007; 131: 1829-33.

11. Smith NM. Broadsheet number 56: Mechanisms of fetal loss. Pathology 2000; 32: 107-15.

12. Laurini R, Laurin J, Marsal K. Placental histology and fetal blood flow in intrauterine growth retardation. Acta Obstet Gynecol Scand 1994; 73: 529-34. [CrossRef]

13. Arias F, Romero R, Joist H, Kraus FT. Thrombophilia: a mechanism of disease in women with adverse pregnancy outcome and thrombotic lesions in placenta. J Matern Fetal Med 1998; 7: 277-86. [CrossRef]

14. Salafia CM, Minior VK, Pezzullo JC, Popek EJ, Rosenkrantz TS, Vintzileos AM. Intra-uterine growth restriction in infants of less than thirty-two weeks' gestation: associated pla-cental pathologic features. Am J Obstet Gynecol 1995; 173: 1049-57. [CrossRef]

15. Salafia CM. Placental pathology of fetal growth restriction. Clin Obstet Gynecol 1997; 40: 740-9. [CrossRef]

16. Katzman PJ, Genest DR. Maternal floor infarction and massive perivillous fibrin deposi-tion: histological definitions, association with intrauterine fetal growth restriction, and risk of recurrence. Pediatr Dev Pathol 2002; 5: 159-64. [CrossRef]

17. Bendon RW, Hommel AB. Maternal floor infarction in autoimmune disease: two cases. Pediatr Pathol Lab Med 1996; 16: 293-7. [CrossRef]

18. Syridou G, Spanakis N, Konstantinidou A, Piperaki ET, Kafetzis D, Patsouris E, et al. Detection of cytomegalovirus, parvovirus B19 and herpes simplex viruses in cases of intraute-rine fetal death: association with pathological findings. J Med Virol 2008; 80: 1776-82. [CrossRef]

19. Vernhof KK, Benirsche K, Kephart GM, Wasmoen TL, Gleich GJ. Maternal floor infarc-tion: relationship to $\mathrm{X}$ cells, major basic protein, and adverse perinatal outcome. Am J Obstet Gynecol 1992; $167 ; 1355-63$.

20. Salafia CM, Minior VK, López-Zeno JA, Whittington SS, Pezzullo JC, Vintzileos AM. Relationship between placental histologic features and umbilical cord blood gases in preterm gestations. Am J Obstet Gynecol 1995; 173: 1058-64. [CrossRef] 